\title{
Factors That Determine the Adoption of Improved Irish Potato Technologies by Farmers in the Western Region of Cameroon
}

\section{Chefor Selahkwe1, Manu Ibrahim Nformi' ${ }^{1}$, Tohnain Nobert Lengah1, Eileen Bogweh Nchanji ${ }^{*}{ }^{\circledR}$, Chefor Fotang 3 (i)}

${ }^{1}$ Department of Rural Socio-Economics and Agricultural Extension, Faculty of Agronomy and Agricultural Sciences, University of Dschang, Dschang, Cameroon

${ }^{2}$ International Center for Tropical Agriculture, Nairobi, Kenya

${ }^{3}$ Department of Ecology, Brandenburg University of Technology Cottbus-Senftenberg, Cottbus, Germany

Email: *e.nchanji@cgiar.org

How to cite this paper: Selahkwe, C., Nformi, M.I., Lengah, T.N., Nchanji, E.B. and Fotang, C. (2021) Factors That Determine the Adoption of Improved Irish Potato Technologies by Farmers in the Western Region of Cameroon. Agricultural Sciences, 12, 1404-1413.

https://doi.org/10.4236/as.2021.1212089

Received: November 8, 2021

Accepted: December 10, 2021

Published: December 13, 2021

Copyright $\odot 2021$ by author(s) and Scientific Research Publishing Inc. This work is licensed under the Creative Commons Attribution International License (CC BY 4.0).

http://creativecommons.org/licenses/by/4.0/

(c) (i) Open Access

\begin{abstract}
This work examined the determinants of the adoption of improved Irish potato technologies by farmers in three divisions of the Western Region of Cameroon. Data were collected from 170 farmers from 14 villages in our study area using a mixed-method approach-structured questionnaires, focus group discussion, key informant interviews, and participatory observations with individual farmers and farmers belonging to cooperative and common initiative groups. The study employed descriptive statistics and regression analysis to assess the adoption status of farmers and its determinants. The logistic regression analysis showed that farmers' experience in the cultivation of potatoes, the number of follow-ups, and access to extension facilities after training had a significant positive effect on the adoption of these new technologies while membership to an association had a significant negative effect. Additionally, farmers who received improved seeds from NGOs were more likely to adopt a technology than those who did not. Our results suggested that constant follow-up and training of experienced farmers and the provision of improved potato seeds have the potential of maintaining high rates of Irish potato adoption west in Cameroon irrespective of whether they belong to cooperative or not. We recommend that the number of follow-ups, extension training, and market linkages for farmers should be increased. Additionally, more farmers should join farmer groups such as cooperatives or common initiative groups to increase their awareness rate and adopt improved potato innovation through farm extension.
\end{abstract}




\section{Keywords}

Adoption, Extension Agents, Farmers Associations, Gender, Potato Farmers, Innovations, Western Cameroon

\section{Introduction}

Growth in the agricultural sector is key to alleviating poverty and food insecurity in developing countries [1]. Agricultural technologies can contribute to poverty reduction, by raising the incomes of farm households and, in some cases, providing new employment opportunities for landless laborers [2] [3]. Low adoption of improved agricultural technologies leads to a decrease in agricultural productivity by small-scale farmers in sub-Saharan Africa [4] [5] [6]. Therefore identifying factors hindering the adoption/uptake of improved agricultural technologies has been an important research agenda. The diffusion of technology by farmers results from a series of individual decisions to use the new technology and decisions often taken based on comparing the benefits costs of adopting it [7]. Additionally, farmers' decisions to adopt a new technology depend on the kind of technology and socio-political and economic factors [8].

Some social factors such as access to extension services, membership to an association, number of follow-up after training, and farmers' experience have been reported to affect the adoption of Irish potato technology by farmers [9] [10] [11] [12] [13]. For instance, [10] reported that the frequency of extension contacts, access to credit services, family labor, access to fertilizers, and participation in training significantly influenced the adoption of improved potato (Belete) variety amongst small-holder in farmers in Southern Ethiopia. [11] found that farmers' access to training and formal quality seeds from sector agencies were more likely to allocate larger areas for improved potato cultivation in mid-hills and Tarai agro-ecological regions in eastern and western Nepal. They further found a negative relationship between farmers' adoption of improved potato, suggesting that farmers with large farm sizes were less likely to adopt improved potato varieties. [13] demonstrated that farmers who had access to extension services were more likely to adopt the technologies than those with limited access in South Western Uganda. [14] reported that farmers' experience, access to credit, and extension services were positively and significantly correlated with the adoption of improved Irish technologies in Mbeya Rural District in Tanzania. At Jeldu district of West Shewa zone and Oromia region, distance to the nearest market, access to extension services, perception towards, and ownership of livestock positively and significantly influenced farmer's decision to adopt improved potato varieties [15].

Ketema et al. 2019 found that membership to cooperatives and social institutions plays a vital role in adopting technologies in Nakuru County in Kenya. At Woreda district in Ethiopia, frequent visits by development and membership to 
cooperative positively affected the adoption of technology [16]. [17] found out that training and sources of potato seeds had a significant positive effect on adopting improved potato technologies in Bara Kailali, Jhapa, Kavre, and Solukhumbu districts in Nepal. At Chitwan, Nepal, the probability of improved potato technology adoption increased upon an increase in the frequency of extension visits and training on potato growing packages [18].

Other factors, including age, sex, level of education, and awareness programs, also influence the adoption of technology by Irish potato farmers [15] [16]. For example, [13] found that male farmers were about more likely to adopt potato technologies than females in South Western Uganda. [9] reported that level of education, farm size, access to credit, and radio and television presence positively influenced farmers' decision to adopt ware potato technology in the Upper Rift Valley Region of Ethiopia. Additionally, [19] reported that farmers with high educational levels were more likely to adopt potato technology Ormia regional state Western Sewa in Southern Ethiopia. In Southern Ethiopia, educational level positively significantly influenced the adoption of improved potato technology [10].

Potato (Solanum tuberosum L) is an essential food crop in Cameroon, and more than $50 \%$ of farmers that grow potatoes come from the West and Northwest region of Cameroons [20] However, farmers from these two regions still face major challenges in potato production, including 1) scarcity of facilities and knowledge on appropriate technology for seed and Irish-potato storage, transformation, and processing, 2) poor agronomic practices, 3) increase spread of foliar and Lubet diseases, like potato blight (Phytophthora infestans), 4) Scarcity of improved, adapted, high-yielding and disease tolerant varieties, and 5) insufficient market system and progressive degeneration of long-time-introduced varieties, without regular replacement [21]. Farmers lack organized seed potato production programs or schemes in Cameroon and depend on buying potato seeds from the market or from farmers who had selected and preserved their seeds [21]. Additionally, most farmers still depend on traditional practices like gathering grass and burning the soil, which destroys the soil microfauna or micro-organisms [21]. More so, most farmers use organic fertilizer (cow dung and chicken dropping) because of limited inorganic fertilizer supplies from the government and supply agencies, leading to low productivity.

Several studies have been carried out on Irish production in Cameroon. For example, [22], found that lack of technical guidance for potato farmers from the Cameroon Agricultural Extension Service was the major problem in adopting two new potato varieties (Cipira and Tubira) in Cameroon. [23] reported that the farmer's age, farmer's experience, the use of manure, and extension services were the most significant determinants of technical efficiency among Irish potato farmers. [23] further found that inappropriate training is the primary cause of inefficiencies in production among small-holder Irish potato farmers in Santa subdivision in the North-West region of Cameroon. Despite these numerous 
studies conducted on the adoption of agricultural technologies in Cameroon, there is little information on the adoption of new Irish potato technologies introduced by NGOs in the Western Region of Cameroon. Additionally, very little information has been documented on the factors associated with adopting improved potato varieties in the Western region of Cameroon. Therefore, this work aims to investigate the factors that affect the adoption of improved Irish potato (Solanum tuberosum L) technologies by farmers in the west region of Cameroon trained by NGOs. We hypothesized the improved potato technology will increase with membership to the associations and cooperatives [16], farmers' experience [14], and educational level of farmers.

\section{Materials and Methods}

\subsection{Study Area}

The West Region occupies $14,000 \mathrm{~km}^{2}$, located in the central-western portion of the Republic of Cameroon, at 50 30'N030E, with 1,865,394 people (Wikipedia, 2013). It borders the Northwest Region to the northwest, the Adamawa Region to the North East, the Centre Region to the southeast, the Littoral Region to the southwest, and the Southwest Region to the West. This region has a pleasant climate due to high elevations and moderate to high humidity. Temperatures are superb, and rainfall is moderate. The West experiences two major seasons; the year begins in a long, dry period of little rain, which runs until May when the rains begin in May or June and last until October or November. Home to the enterprising Bamileke (Bamiléké) tribes, the West is an economic bright spot and one of Cameroon's more developed regions, cultivating Irish potato, one of the major crops. The Bamileke are skilled farmers who exploit virtually every strip of land available. The West supplies most of the food consumed in Cameroon's seven lower provinces and the neighboring Northwest Province. Farmer's plant after the first rains in fields consisting of alternating ridges and furrows. In the past, farmers practiced field rotation, allowing land to fallow for two or three years. However, due to increasing population density, they use the land almost continuously today; the loss in fertility is partially countered through extensive use of fertilizers and manure. Tools are primarily traditional.

\subsection{Sampling Technique and Data Collection}

The western region was divided into 8 divisions namely; Bamboutos, Haut-Nkam, Hauts-Plateaux, Koung-Khi, Ménoua, Mifi, Ndé, Noun. Three divisions (Menoua, Mifi, and Bamboutos) were purposefully selected for our study because of high potatoes production and the presence of Irish potatoes technology extension NGO (Figure 1). Four to five villages were purposefully selected from each subdivision with a multitude of cooperatives and common initiative groups and farmers who have initially benefited from training from NGO and other private organizations and were involved in Irish potato cultivation since 2018. 


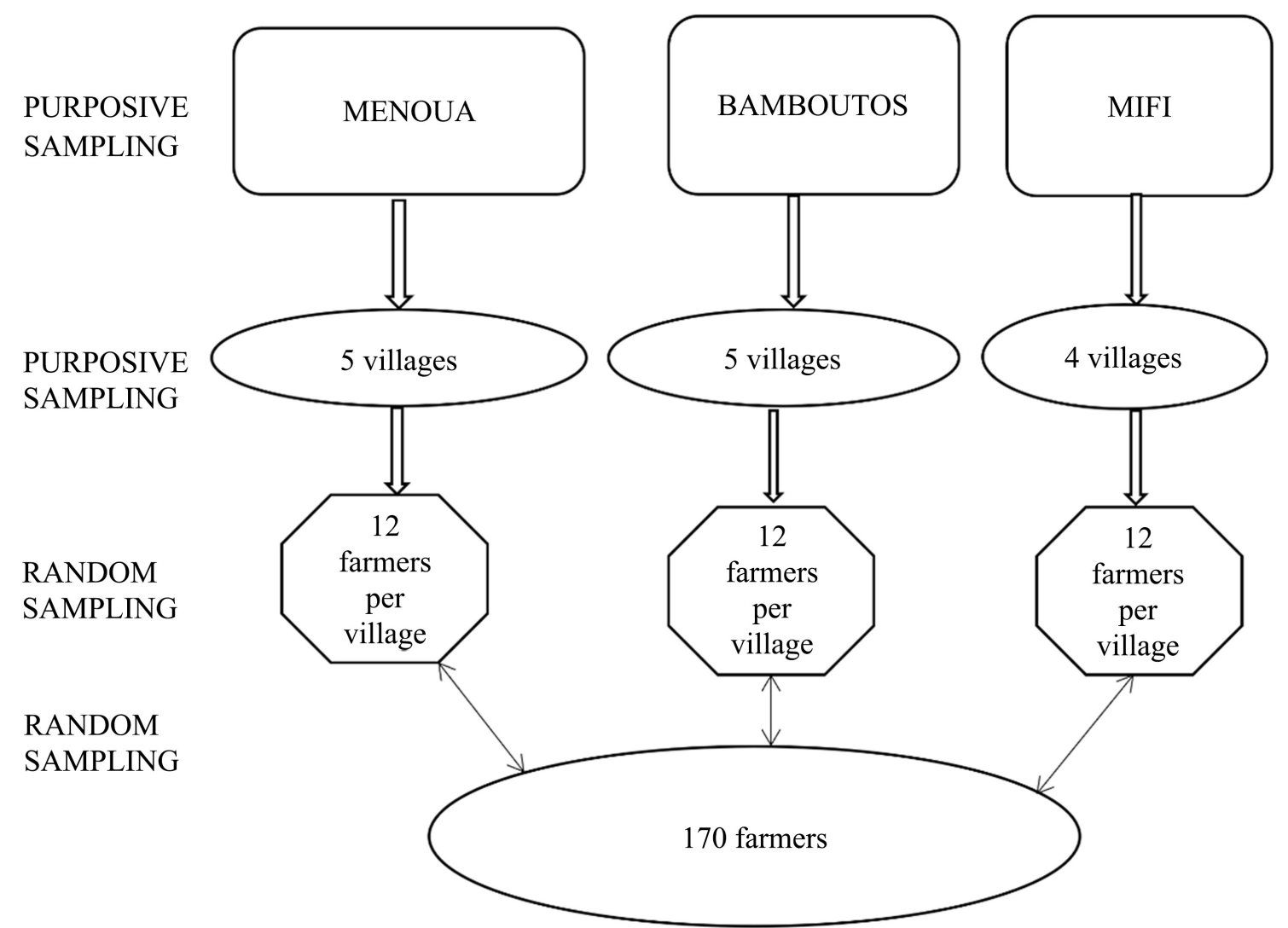

Figure 1. Schematic representation of the sampling procedure used in the selection of farmers for semi-interview administration.

\subsection{Data Collection}

Data collection took place between January and March 2020. One focus group discussion of 25 (7 men and 18 women) was organized per village. Simple random sampling was used to select 12 farmers per village using a list of farmers who NGO agents trained in 2018 on modern techniques of Irish potato resulting in 170 farmers (Figure 1). Additionally, 170 semi-structured questionnaires administered were conducted with 170 farmers' and farmers were asked if they adopted the technology diffused by NGO or not. Furthermore, questions related to factors that affect the adoption of potato technology such as age, sex, and level of education, source of revenue, number of follow-ups after training, membership to an association and farmers' experience in the cultivation of Irish potations were asked.

\section{Data Analysis}

Questionnaires were decoded, data entered into Microsoft Excel 2016, and exported into SPSS version 26 for statistical analyses. The normality of residuals was checked with the Shapiro-Wilk normality test and homogeneity of variances using the Levene test. A binary logistic regression (Hosmer and Lemeshow, 2000; Cavane, 2011) was performed using the GLM (generalized linear model) 
function and a family binomial to investigate the factors affecting Irish potato technologies' adoption. We used a binary logistic regression model (Equation (1)) because our dependent variable was binary ( 1 if farmer adoption at least a technology and 0 for no adoption). Multicollinearity in our model was checked using a Spearman correlation test, and highly correlated independent variables were removed. Additionally, Kruskal Wallis Anova was used to compare the adoption rate of farmers who received improved seeds from NGOs to farmers who did not receive seeds.

$$
Y_{i}=a+b X_{i}+E_{i}
$$

where $Y_{i}$ is the dependent variable (Adoption decision), $X_{i}(i=1,2,3,4, \ldots, n)$ is a set of independent variables (age, sex, farmers experience, number of follow-ups, level of education, source of revenue, farm size, farmers experience, land ownership, use of improved seeds), $b$ is constants, and $E_{i}$ is the error

\section{Results and Discussions}

The logistic regression showed that the number of follow-ups after training and farmers' experience had a significantly positive effect on the adoption of new technologies introduced by NGOs, while membership to an association had a significant negative effect on the adoption rate of new potato technologies (Table 1).

The number of follow-ups and access to extension facilities after training had a significant positive effect on the adoption of technology. An increase in one unit of follow-up leads to a 1.3 unit increase in the rate of adoption. Results from interviews and group discussion revealed that a majority of farmers, 151 (88.3\%), were follow-up at least two times after training, while 19 (11.3\%) were not followed up. Our results are in line with those of [13] in southwestern Uganda, and Oromia region, in Ethiopia [15], where farmers who had access to extension services were more likely to adopt the technologies than those with limited access.

Table 1. Binary logistic regression model on factors determining the rate of adoption of Irish Potato.

\begin{tabular}{ccccccc}
\hline Variable & Coefficient & S.E & Wald & df & P-Value & Exp(B) \\
\hline Constant & 1.763 & 2.237 & 0.621 & 1 & 0.431 & 5.833 \\
Sex & -1.191 & 0.806 & 2.183 & 1 & 0.140 & 0.304 \\
Educational level & 0.134 & 0.536 & 0.062 & 1 & 0.803 & 1.143 \\
Source of revenue & -0.222 & 0.287 & 0.595 & 1 & 0.440 & 0.801 \\
Land area unders potato & 0.274 & 0.298 & 0.847 & 1 & 0.357 & 1.316 \\
$\begin{array}{c}\text { Followups/access to extension } \\
\text { facilities }\end{array}$ & 1.385 & 0.429 & 10.446 & 1 & 0.001 & 3.996 \\
membership to and association & -0.908 & 0.338 & 7.237 & 1 & 0.007 & 0.403 \\
Experience & 1.007 & 0.346 & 8.483 & 1 & 0.004 & 2.737 \\
\hline
\end{tabular}


As predicted, farmers' experience positively and significantly affected the adoption rate of improved potato technologies. This implies that an increase in one unit of experience of a farmer leads to an increase in a 0.9 unit in the adoption of technology. Therefore farmers who had more years of experience in cultivating potatoes were more likely to adopt than those who had lesser or no years of experience. Moreover, farmers with more than five years of experience 126 (74\%) in potato cultivation were adopters, while those below five years 44 (26\%) of experience mainly were non-adopters. The Kruskal-Wallis test further showed that farmers above ten years were more likely to adopt technology than those below five years (Kruskal-Wallis, $\mathrm{P}=0.00$ ). Our results are also in line with finding from Mbeya Rural district in Tanzania [14], where increased farming experience had a positive significance associated with overall adoption. Our results contradict [24] at Bara district in Nepal, where farmers' experience did not considerably affect improved potatoes' adoption. This difference could be due to the difference in regions.

Although most farmers belong to cooperative (43.5\%), common initiative groups $(30.6 \%)$, and farmers association $(21.2 \%)$ in our study, results from the logistic regression model revealed that membership to an association negatively correlated with the adoption of improved potato technology in Western Cameroon (Table 1). During interview and focus group discussions, farmers complained of limited access to credits and mismanagement of cooperative funds by cooperative leaders. Additionally, farmers only came to the cooperative to buy seeds and were unwilling to participate in meetings organized by the cooperative leaders because they did not trust them. Contrary to our findings, membership to cooperatives had a significant positive on potato technology in adoption $\mathrm{Na}$ kuru County, Kenya [12] and Oromia region, in Ethiopia [15].

Most farmers trained 150 (80\%) received improved potato seed varieties, while 20 (20\%) did not. As a consequence, farmers who received improved Irish potato seeds from NGOs (mean rank $=149.25$ ) were more likely to adopt a technology than those who did not receive seeds (Mean rank $=77.00$, Kruskal-Wallis $\mathrm{H}=$ 79.219 , df, $1, \mathrm{P}=0.000, \mathrm{~N}=170$ ). A majority of farmers who received improved seeds from NGOs in our study adopted the diffused technology giving reasons that improved yields from improved breeds were higher than those of local seed. They further argued that improved potato fruits were highly demanded and preferred by buyers in the markets over local breeds. Similarly, [17] found out that sources of potato seeds were seen to be the major significant factors affecting the proportion of areas allocated for improved potato production in Bara Kailali, Jhapa, Kavre and Solukhumbu districts in Nepal. [25] suggested that the adoption of improved potato varieties in combination with management practices like early planting and application of fertilizers had potential of increasing Irish potato productivity at Rubanda district in South Western Uganda. In contrast to our results, improved seed did not influence ware potato farmers to adopt new varieties in Upper Rift Valley region in Ethiopia because the new va- 
rieties were not available and were very expensive [9]. Additionally, farmers reported that local varieties could be easily managed and had better stew quality attributes than improved varieties, in South Western Uganda.

Contrary to our results, [13] reported that gender significantly affected the adoption rate and male farmers were about more likely to adopt the technology. The non-significant effect of gender in our results could be that both males and females were involved in potato farming and therefore adopted technology at equal rates in Western Cameroon compared to Uganda. Other factors such as age, educational level, source of revenue, land ownership were not significant factors in adopting potato technologies in Western Cameroon. This implies that these factors are not good predictors of the adoption of potato technologies in our study area. These results contradict those of [26] and [6], in which these factors were significant. These again show that the determinants of technology adoption are contextual and not supposed to be generalized.

\section{Conclusion}

We showed that the number of follow-ups and access to extension facilities after training and the number of years involved in Irish potato farming (experience) significantly affect Irish potato farmers' decisions to adopt new potato technologies in Western Cameroon. Additionally, farmers who received improved seeds from NGOs were more likely to accept and practice the technologies diffused. Belonging to an association negatively influenced farmers' decision to adopt technology because of mismanagement of funds and poor collaboration between farmers and leaders of the association. Our results suggest that regular follow-up of individual farmers after training can increase their decision to adopt a technology. We recommend regular follow-up of farmers and that more farmers should join farmer groups such as cooperatives to increase their awareness rate and the opportunity to receive improved seed. We recommend the development of a good memorandum of understanding between farmers and leaders of association and transparency in the management of funds and other benefits generated from the running of farmers association.

\section{Acknowledgements}

I am grateful to Prof. Manu Ibrahim Nformi, Prof. Tohnain for their invaluable support and guidance throughout my Ph.D. project. I thank. Pr. Guillaume Fongang, Fon Dorothy, JAZA FOLEFACK Achille Jean, their helpful comments and contributions during departmental seminars. I thank Georges Tadjiotio Ngougni, Coordinator of the GADD (Support Group for Sustainable Development), who integrated me into his project and always created time to clarify some doubts during the data collection phase. I thank Mr. Fotang Chefor and Dr. Eileen Bogweh Nchanji for their significant contributions to data analyses and the writing of this manuscript. I thank my parent Mr. Chefor Mba Devine and Ngwe Florence, for their prayers. 


\section{Conflicts of Interest}

The authors declare no conflicts of interest regarding the publication of this paper.

\section{References}

[1] World Bank (2007) World Development Report 2008: Agriculture for Development. The World Bank, Washington DC.

[2] Winters, P., de Janvry, A., Sadoulet, E. and Stamoulis, K. (1998) The Role of Agriculture in Economic Development: Visible and Invisible Surplus Transfers. The Journal of Development Studies, 34, 71-97. https://doi.org/10.1080/00220389808422537

[3] Noltze, M., Schwarze, S. and Qaim, M. (2013) Impacts of Natural Resource Management Technologies on Agricultural Yield and Household Income: The System of Rice Intensification in Timor Leste. Ecological Economics, 85, 59-68. https://doi.org/10.1016/j.ecolecon.2012.10.009

[4] Du, O.-O. and Onemolease, E.A. (2009) Factors Affecting the Adoption of Yam Storage Technologies in the Northern Ecological Zone of Edo State, Nigeria. Journal of human Ecology, 27, 155-160. https://doi.org/10.1080/09709274.2009.11906205

[5] Omoregbee, F. and Du, O.-O. (2008) Farmers Ćharacteristics and Adoption of Recommended Practices under the Fadama Project Scheme in Edo State, Nigeria. Global Journal of Agricultural Sciences, 7, 45-48. https://doi.org/10.4314/gjass.v7i1.2358

[6] Salasya, B., Mwangi, W.M., Mwabu, D. and Diallo, A. (2007) Factors Influencing Adoption of Stress-Tolerant Maize Hybrid (WH 502) in Western Kenya. African Journal of Agricultural Research, 2, 544-551.

[7] Hall, B.H. and Khan, B. (2002) Adoption of New Technology. In: New Economy Handbook. Berkeley University, Berkeley, 1-38. https://doi.org/10.3386/w9730

[8] Lavison, R.K. (2013) Factors Influencing the Adoption of Organic Fertilizers in Vegetable Production in Accra. University of Ghana, Accra

[9] Abebe, G.K., Bijman, J., Pascucci, S. and Omta, O. (2013) Adoption of Improved Potato Varieties in Ethiopia: The Role of Agricultural Knowledge and Innovation System and Smallholder Farmers' Quality Assessment. Agricultural Systems, 122, 22-32. https://doi.org/10.1016/j.agsy.2013.07.008

[10] Feleke, A., Regasa, G. and Muche, M. (2019) Factors Influencing Adoption of Improved Potato (Belete) Variety: Evidence from Ethiopian Smallholder Farmers. Journal of Agricultural Science, 30, 85-92. https://doi.org/10.15159/jas.19.17

[11] Gairhe, S., Gauchan, D. and Timsina, K. (2017) Adoption of Improved Potato Varieties in Nepal. Journal of Nepal Agricultural Research Council, 3, 38-44. https://doi.org/10.3126/jnarc.v3i1.17274

[12] Ketema, M., Kebede, D., Dechassa, N. and Hundessa, F. (2016) Determinants of adoption of potato production technology package by smallholder farmers: Evidences from Eastern Ethiopia. Review of Agricultural and Applied Economics, 19, 61-68. https://doi.org/10.15414/raae.2016.19.02.61-68

[13] Mwanja, W., Alinda, F. and Kiwanuka, M. (2016) Factors Affecting Farmers' Adoption of Improved Irish Potato Seed Production Technologies in South Western Uganda. International Journal of Agricultural Science and Research, 6, 503-512

[14] Namwata, B.M.L., Lwelamira, J. and Mzirai, O.B. (2010) Adoption of Improved 
Agricultural Technologies for Irish Potatoes (Solanum tuberosum) among Farmers in Mbeya Rural District, Tanzania: A Case of Ilungu Ward. Journal of Animal \& Plant Sciences, 8, 927-935.

[15] Ogeto, M.A., Mohammed, J.H. and Bedada, D.G. (2019) Adoption of Improved Potato Varieties in Jeldu District, Oromia Region, Ethiopia: A Double-Hurdle Model. International Journal of Agricultural Research, Innovation and Technology, 9, 15-22. https://doi.org/10.3329/ijarit.v9i2.45405

[16] Abreham, G. and Sete, Y. (2019) Adoption of Improved Potato Variety: The Case of Dabatworeda, Ethiopia. Indian Journal of Economics and Development, 7, 1-9.

[17] Upadhyay, N., Ghimire, Y.N., Acharya, Y. and Sharma, B. (2020) Adoption of Improved Potato Varieties in Nepal. Black Sea Journal of Agriculture, 3, 139-145.

[18] Ghimire, N. (2005) Adoption of Improved Potato Technology in Chitwan, Nepal. Economic Journal of Nepal, 28, 188-199. https://doi.org/10.3126/ejon.v28i3.174

[19] Worku, A.A. (2019) Factors Affecting Diffusion and Adoption of Agricultural Innovations among Farmers in Ethiopia Case Study of Ormia Regional State Westsern Sewa. International Journal of Agricultural Extension, 7, 137-147. https://doi.org/10.33687/ijae.007.02.2864

[20] Foncho, P.A. (1989) Future Plans and Strategies for Potato Research in Cameroon. In: Potato Production and Constraints in West and Central Africa: Overview and Planning Strategies for the Future, Bamenda (Cameroon), 25-30 September 1988, 33-34. https://pdf.usaid.gov/pdf docs/pnabd866.pdf

[21] Martin, C., Demo, P., Gass, T., Fondong, V. and Koi, J. (1995) Development of a Seed Production System from in-Vitro in Cameroon: Experiences from the First Two Years. American Potato Journal, 72, 299-302. https://doi.org/10.1007/BF02849283

[22] Deffo, V. and Demo, P. (2003) Adoption of Two New Potato Varieties in Cameroon: Progress and Constraints. American Journal of Potato Research, 80, 263-269. https://doi.org/10.1007/BF02855362

[23] Mengui, K.C., Oh, S. and Lee, S.H. (2019) The Technical Efficiency of Smallholder Irish Potato Producers in Santa Subdivision, Cameroon. Agriculture, 9, Article No. 259. https://doi.org/10.3390/agriculture9120259

[24] Kafle, B. and Shah, P. (2012) Adoption of Improved Potato Varieties in Nepal: A Case of Bara District. Journal of Agricultural Sciences-Sri Lanka, 7, 14-22. https://doi.org/10.4038/jas.v7i1.4063

[25] Mugagga, F., Nimusiima, A. and Elepu, J. (2020) An Appraisal of Adaptation Measures to Climate Variability by Smallholder Irish Potato Farmers in South Western Uganda. American Journal of Climate Change, 9, 228-242. https://doi.org/10.4236/ajcc.2020.93015

[26] Saka, J.O., Okoruwa, V.O., Lawal, B.O. and Ajijola, S. (2005) Adoption of Improved Rice Varieties among Small-Holder Farmers in South-Western Nigeria. World Journal of Agricultural Sciences, 1, 42-49. 